\title{
ECOLOGICAL STATUS OF SAND BINDER PLANT WHITE SAXAUL (HALOXYLON PERSICUM) AT THE MANAGED AREA OF AL-QASSIM, SAUDI ARABIA: PLANT ASSOCIATIONS AND POPULATION STRUCTURE
}

\author{
ELMEFREGY, M. $.^{*}-$ EL-SHEIKH, M. A. ${ }^{1,2}$ \\ ${ }^{1}$ King Saud University, College of Science, Botany \& Microbiology Department \\ B.O. Box 2455, Riyadh 11451, Saudi Arabia \\ ${ }^{2}$ Damanhour University, Faculty of Science, Botany \& Microbiology Department, Damanhour, \\ Egypt \\ *Corresponding author \\ e-mail:melmefregy@outlook.com \\ (Received $8^{\text {th }}$ Sep 2019; accepted $8^{\text {th }}$ Jan 2020)
}

\begin{abstract}
Haloxylon persicum is a desert shrub with economic and ecological importance for arid zones in Saudi Arabia. It has a vital role in the protection of Unaizah and Buraidah, two large cities, and their surrounding from the dangerous mobile sand dunes and without it, the area could be covered by these dunes in a few years. The current study aims to analyze the floristic, vegetation structure and size structure of $H$. persicum. Eighteen stands were selected along the north and south of the study area with $20 \mathrm{~m}^{2}$ each. At each stand, the vegetation inventory including plant species abundance percentage and size structure for $H$. persicum were estimated. Three plant associations; H. persicum-Plantago boissieri, $H$. persicum-Stipagrostis plumose and H. persicum were identified. Analysis of $H$. persicum size structure frequency was skewed towards medium size classes in all populations and the early life stages such as juvenile and the seedling recruitment was extremely limited. These results indicated that the populations of $H$. persicum are threatened by aridity and human impacts. Therefore, efforts are required to minimize uncontrolled exploitation. Finally, in situ and ex situ conservation of $H$. persicum populations are strongly recommended.
\end{abstract}

Keywords: human impact, managed area, population demography, seedling recruitment, size structure

\section{Introduction}

Sand dunes are one of the largest arid terrestrial ecosystems in Saudi, covering huge area of land surface (Reynolds et al., 2007). This sandy arid dry land is a fragile ecosystem component and one of the most sensitive areas to climate change and human activities, because the rare of rainfall and high evapotranspiration (Huang et al., 2015). Conversely, there are a lot of groundwater under these sand dunes due to the seeping of the rainfall water through the sand layers and stored against the evapotranspiration. These quantities of underground water are often an important water source for perennial plants and can be used for cultivation of farms (Cui and Shao, 2005; Naumburg et al., 2005; Imada et al., 2008). Moreover, the dynamics and the availability of the groundwater plays an important role in defining vegetation composition and distribution (Naumburg et al., 2005; Elmore et al., 2006), and in driving the vegetation dynamic and shifting the interactive balance between wooden species and herbaceous plants (Cooper et al., 2006; Holzapfel et al., 2006; McCluney et al., 2012). The unsustainable exploitation of groundwater associated with rapid population expansion and socio-economic development in these regions has aggravated the fluctuation of the groundwater table and influenced the availability of groundwater to desert shrub plants 
(Wang et al., 2011; Orellana et al., 2012). Declining or shifting the area of vegetation will decrease the diversity of plant associations and the stability of sand dunes this can consequently result in covering of the cities and productive farms by sands (Naumburg et al., 2005; Padilla and Pugnaire, 2007).

$H$. persicum is one of the most characteristic communities inhabit the Nafud habitat (flat sand seas with high sand dune) and characteristically occupies deep sand on the shoulders of sand dunes and shallow hollows of center Saudi (Schulz and Whitney, 1986). It nearly corresponds to the Calligonum comosum and Artemisia monosperma shrubland. H. persicum is an important plant for binding the mobile sand and shelter for many other plant associations which increasing the plant diversity (Brown and Porembski, 1998; El-Sheikh et al., 2010). Removal of $H$. persicum and Calligonum comosum for using as fuel and Stipagrostis by heavy gazing are common anthropogenic practices in Al-Qassim area. Therefore, people are managed this area at Unaizah from long time ago. Because, this managed area is the main reason for saving Unaizah and Buraydah cities and farms against the common dangerous sandy storms with strong mobile sand dunes. Without a dominant $H$. persicum and its associations, the area will be covered by mobile sand dunes in few years. However, there have been only few studies on the status of woody vegetation such as (Alatar et al., 2015). Therefore, understanding the mechanisms underlying the size, shape and dynamics of the geographic distributions of various species remains a key challenge (Pennisi, 2005; Gaston, 2009).

However, the present study aims to: 1- analysis the floristic and vegetation structure of managed area, 2- examine the status of $H$. persicum size structure if the population grow or decline after the long period of protection, and 3- analysis the ecological relations of $H$. persicum with edaphic and dominant anthropogenic factors.

\section{Materials and methods}

\section{Study area}

Al-Ghada managed area is located in Nafud Al-Shuqayyqah 'sandy arc'. It is located in the center of Al-Qassim area, south-west of Unaizah city and south of Wadi Al-Rumah valley between $43^{\circ}-44^{\circ}$ E $25^{\circ}-26^{\circ} \mathrm{N}$, lat. 630-724 meters above sea level (Figure 1). It is surrounded by sand dunes from the north and the west called the sands of Ghamis. The presence of $H$. persicum on the deep sand habitat, often in the form of low sand dune and extended to covering large area with low cover and it only scattered hummocks are to be seen in the landscape. There are associated few sub-shrubs, perennial grasses and annuals indicate a shallow ground water table fed by percolation.

According to the data of the meteorological station in Qassim region, the study area is located in the arid regions of Saudi Arabia. The climate is mildly moderate as the temperature reaches $20.0^{\circ} \mathrm{C}$ around the day during winter season and at night it is cold as the temperature drops to $6.0^{\circ} \mathrm{C}$. Daytime temperatures reach up to $44^{\circ} \mathrm{C}$ and at night $27^{\circ} \mathrm{C}$ in the summer season.

\section{Sample stands}

A total of 18 stands in the north and south sector of the managed area were selected to covering all variations of habitats and vegetation structure. To analyze floristic and vegetation structure, in each stand plants were collected, identified and classified into 
their different life forms and chorotypes were recorded. Identification of plant species were conducted based on available references (Collenette, 1985, 1998, 1999; Chaudhary, 2001). Plant species cover were estimated in each stand as abundance percentage according to Kent (2012) and Canfield (1941).

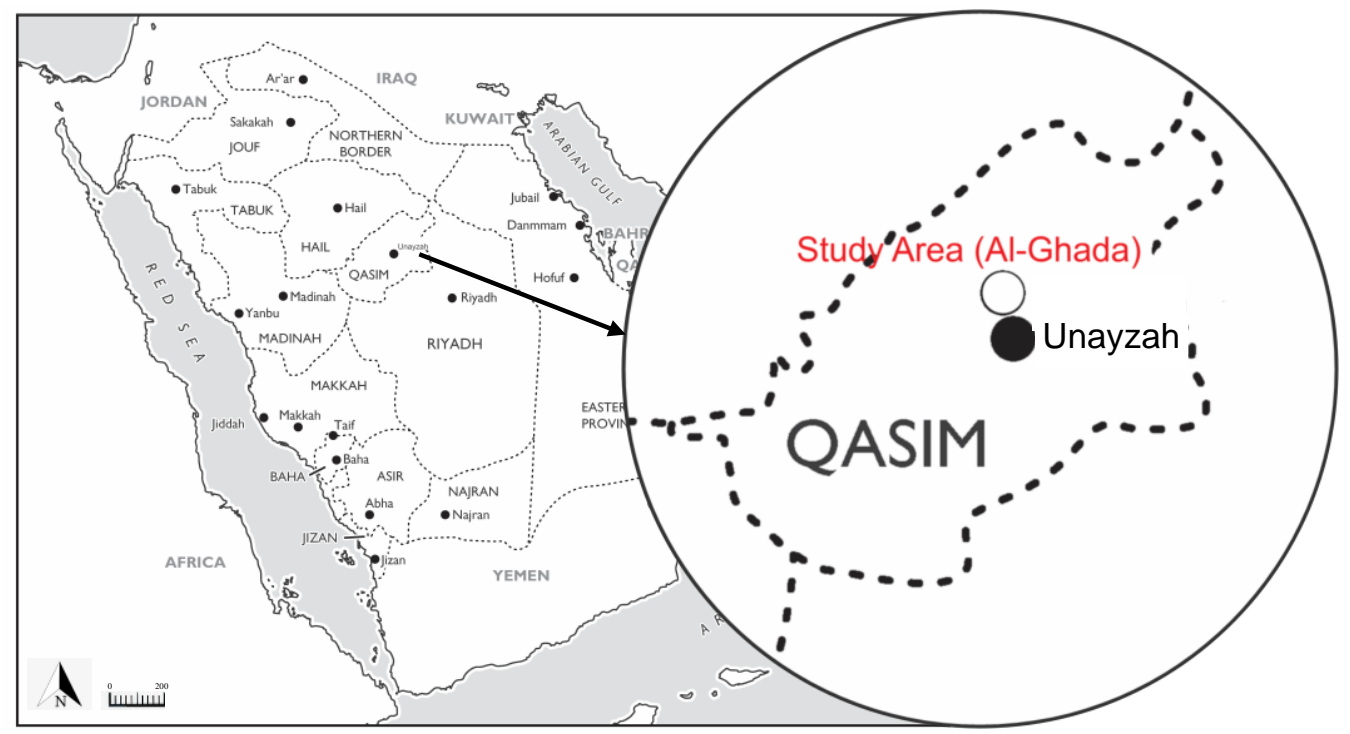

Figure 1. A map showing the study in site at Unaizah area (Source: Ministry of Petroleum and Mineral Resources, Saudi Arabia)

\section{Soil analysis}

Eighteen soil samples were collected; one from each stand from 0 - $50 \mathrm{~cm}$ depth. Soil texture (sand, silt and clay) was analyzed by Hydrometer method (Allen, 1989). The percentage of total organic matter was determined by loss of ignition of soil at $550^{\circ} \mathrm{C}$ for 2 hours. The prepared soil water extract (1:5) was used for further chemical analysis. Soil reaction $(\mathrm{pH})$ measured by $\mathrm{pH}$-meter and electrical conductivity $\left(\mathrm{EC}\right.$ in $\left.\mathrm{mS} \mathrm{cm}{ }^{-1}\right)$ was measured by conductivity -meter. The soil content of nutrient elements (N, P, K, $\mathrm{Ca}, \mathrm{Mg}, \mathrm{Na}$ and $\mathrm{Fe}$ ) was estimated by using Inductively Coupled Plasma Optical Emission Spectrometry (ICP MSEOS 6000 Series, Thermo Fisher Scientific) method. All these methods are outlined in Allen (1989).

\section{Data analysis}

The numerical classification analysis TWINSPAN using two-way indicator species analysis (Hill, 1979b) were applied for plant species cover in 18 sample studied i.e matrix of 18 stand x 35 species cover values; and Detrended Correspondence Analysis (DCA) using DECORANA software (Hill, 1979a; ter Braak and Smilauer, 2002) was applied on the same data to obtain a graphical representation of the ecological structure of the vegetation groups identified using TWINSPAN. The second matrix of 18 stand $X$ 35 species cover values $\mathrm{X}$ soil variables was using for detecting the correlations of the derived vegetation groups with environmental data, Canonical Correspondence Analysis, 'CCA', according to ter Braak and Smilauer (2002). 
Species richness of each vegetation group was calculated as the average number of species stand ${ }^{-1}$. Simpson index following the equation $C=\sum_{i=1}^{s} p_{i}^{2}$ as an indicator for the relative dominance concentration and Shannon-Wiener index following the equation $\widehat{\mathrm{H}}=-\sum_{\mathrm{i}=1}^{\mathrm{s}} \mathrm{p}_{\mathrm{i}} \log \mathrm{p}_{\mathrm{i}}$ were calculated for each stand on the basis of the relative cover (pi) of $i$ th species (Pielou, 1975; Magurran, 1988). The correlation between the ordination axes on one hand and soil variables on the other hand were estimated by Pearson's simple linear correlation coefficient (r). Moreover, the relations between species diversity indices and soil variables were tested. The variation in species diversity, soil variables and stand characters in relation to vegetation group was assessed by one-way analysis of variance SPSS 20.0 software, IBM, Chicago, IL.

\section{Plant size structure analysis}

The size of $H$. persicum individuals were counted by their height $(\mathrm{H})$ and average crown diameter (D) were measured (based on 3-diameter measurements/individual) and their average of $H$ and $D$ were calculated in each stand. The size index $H+D / 2$ was calculated (modified Crisp and Lange, 1976). This obtained value used for calculation the size frequency distribution category of $H$. persicum. The frequency of each category is calculated separately as a percentage frequency and drawing graphically. Density of Haloxylon persicum in the studied area was calculated as the number of individuals/ha. Finally, the mean and coefficient of variation of density, height, diameter, and size index of $H$. persicum were calculated.

\section{Results}

\section{Floristic diversity}

A total of 35 plant species belonging to 12 families were collected from the studies stands. The most represented families in the study area were Poaceae and Caryophyllaceae (21\% each), Boraginaceae (18\%) and Geraniaceae (7\%). The most prominent life forms (Figure $2 a$ ) were annual herbs (61\%), sub-shrubs (12\%), annual grasses $(9 \%)$, perennial herbs $(6 \%)$, perennial grasses $(6 \%)$ and shrubs $(6 \%)$. The dominant chorotypes were the Saharo Arabian region represented by 12 species $(41 \%)$ followed by the Mediterranean-Irano Turanian-Saharo Arabian (17\%), the Saharo Arabian-Somali Masai (14\%) and the Saharo Arabian-Irano Turanian (10\%) (Figure 2b).
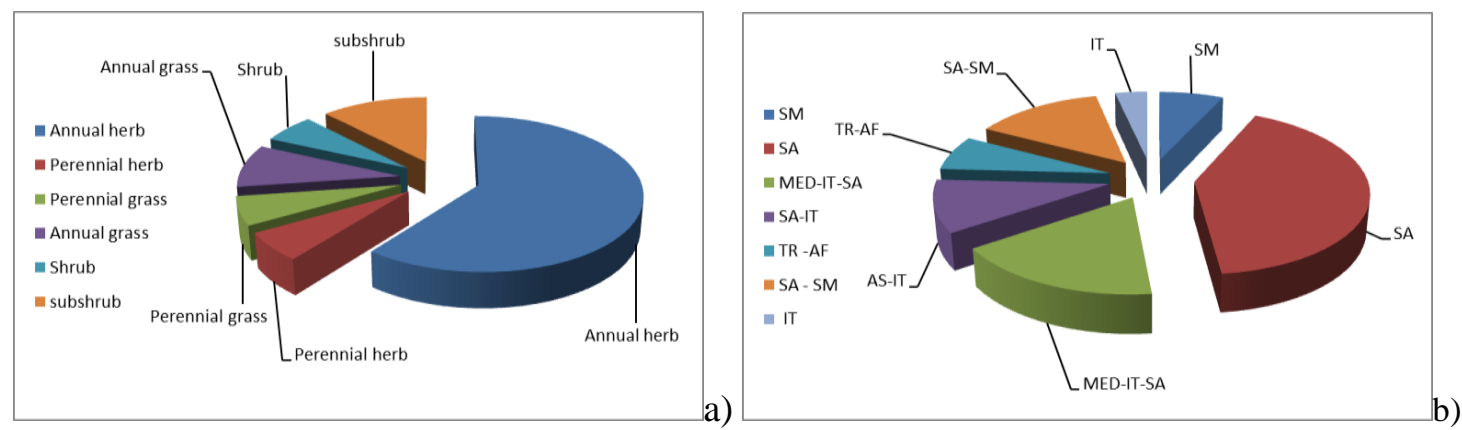

Figure 2. The represented a) life forms and different represented $b$ ) chorotypes in the study area. SA: Saharo-Arabian, MED: Mediterranean, IT: Irano Turanian, SM: Somali Masai, TRAF: Tropical Africa 


\section{Multivariate analysis}

The dataset formed in this study consisted of 18 studied stands and 35 species. TWINSPAN analysis of this dataset generated a dendrogram divided it into three vegetation groups (plant communities) at the second level. Characterization and nomination of these groups were assigned based on the dominant and subdominant species in each group as follows: vegetation group (VG) I: H. persicum-Plantago boissieri, VG II: H. persicum- Stipagrostis plumosa, VG III: H. persicum. Further CCA and DCA analysis confirmed the separation of these plant communities generated by TWINSPAN and reveals a great relationship between topographic aspects and environmental gradients in Ghada managed area (Table 1 and Figure 3a,b). The association VG I: $H$. persicum-Plantago boissieri mostly inhabits on the north sector of managed area $(75 \%)$ of total stands and the association II: H. persicum- Stipagrostis plumosa inhabits mostly on the south zone (57\%) of total stands. On the other hand, the association III $H$. persicum is completely inhabited on the north sector of the managed area (Table 2).

Table 1. Percentage frequency synoptic table

\begin{tabular}{|c|c|c|c|c|c|}
\hline $\begin{array}{l}\text { Group No. } \\
\text { No. of relevés } \\
\% \text { No. of releve in North sector } \\
\% \text { No. of releve in South sector } \\
\end{array}$ & Life forms & Chorotype & $\begin{array}{c}\text { VG I } \\
8 \\
75 \\
25 \\
\end{array}$ & $\begin{array}{c}\text { VG II } \\
7 \\
43 \\
57 \\
\end{array}$ & $\begin{array}{c}\text { VG III } \\
3 \\
100 \\
0 \\
\end{array}$ \\
\hline Haloxylon persicum & SH & IT & 100 & 86 & 100 \\
\hline Schismus barbatus & AG & SA-IT & 50 & 71 & 33 \\
\hline Eremobium lineare & $\mathrm{AH}$ & SA & 63 & 71 & 33 \\
\hline Plantago boissieri & $\mathrm{AH}$ & SA & 75 & 71 & 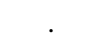 \\
\hline Stipagrostis plumosa & PG & SM & 50 & 43 & 33 \\
\hline Bassia muricata & $\mathrm{AH}$ & SA & 38 & 43 & 67 \\
\hline Neurada procumebens & $\mathrm{AH}$ & SA & 38 & 43 & . \\
\hline Launaea capitata & $\mathrm{AH}$ & MED-IT-SA & 25 & 29 & 33 \\
\hline Silene villosa & $\mathrm{AH}$ & MED-IT-SA & & 29 & 67 \\
\hline Moltkiopsis ciliata & SS & SM & 38 & 14 & 67 \\
\hline Haloxylon salicornicum & SH & SA & 25 & 43 & 33 \\
\hline Hypecoum littorale & $\mathrm{AH}$ & ME & & 14 & 33 \\
\hline Ifloga spicata & $\mathrm{AH}$ & MED-IT-SA & 13 & 14 & . \\
\hline Salsola arabica & SS & SA & 25 & 43 & . \\
\hline Paronychia arabica & $\mathrm{AH}$ & TR -AF & 25 & 29 & . \\
\hline Polycarpaea repens & SS & SA & 13 & & . \\
\hline Gastrocotyle hispida & $\mathrm{AH}$ & SA-IT & . & 29 & . \\
\hline Bassia eriophora & $\mathrm{AH}$ & SA-IT & 13 & 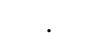 & \\
\hline Centropodia forsskalei & PG & SA & 38 & . & 33 \\
\hline Cakile arabica & $\mathrm{AH}$ & SA & 13 & 14 & 33 \\
\hline Astragalus schimperi & $\mathrm{AH}$ & SA & . & . & 33 \\
\hline Stipa capensis & $\mathrm{AH}$ & SA-SM & & 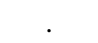 & . \\
\hline Anthemis deserti & $\mathrm{AH}$ & SA & 13 & . & . \\
\hline Senecio glaucus & $\mathrm{AH}$ & IT & 13 & & . \\
\hline Aristida adscensionis & PG & MED-IT-SA & 13 & & . \\
\hline Erodium laciniatum & $\mathrm{AH}$ & MED-IT-SA & 13 & 14 & 67 \\
\hline Launaea mисronata & $\mathrm{AH}$ & SA-SM & 13 & . & . \\
\hline Heliotropium digynum & SS & SA - SM & 13 & . & 33 \\
\hline Gisekia pharnaceoides & $\mathrm{AH}$ & $\mathrm{TR}-\mathrm{AF}$ & 13 & . & . \\
\hline Cynomorium coccineum & PH & ME & 13 & . & . \\
\hline Cutandia memphitica & $\mathrm{AG}$ & SA & 13 & 14 & 33 \\
\hline Malva parviflora & $\mathrm{AH}$ & SA-SM & . & 29 & 33 \\
\hline Monsonia nivea & $\mathrm{AH}$ & Med - IT & 13 & & \\
\hline
\end{tabular}

VG I: Haloxylon persicum-Plantago boissieri; VG II: Haloxylon persicum-Stipagrostis plumosa; VG III: Haloxylon persicum. Life forms are: AH: Annual Herbs, PH: Perennial Herbs, AG: Annual Grasses, Perennial Grasses, SH: Shrubs, SS: Sub-Shrubs. Chorotypes are: SA: Saharo-Arabian, MED: Mediterranean, IT: Irano Turanian, SM: Somali Masai, TR-AF: Tropical Africa 


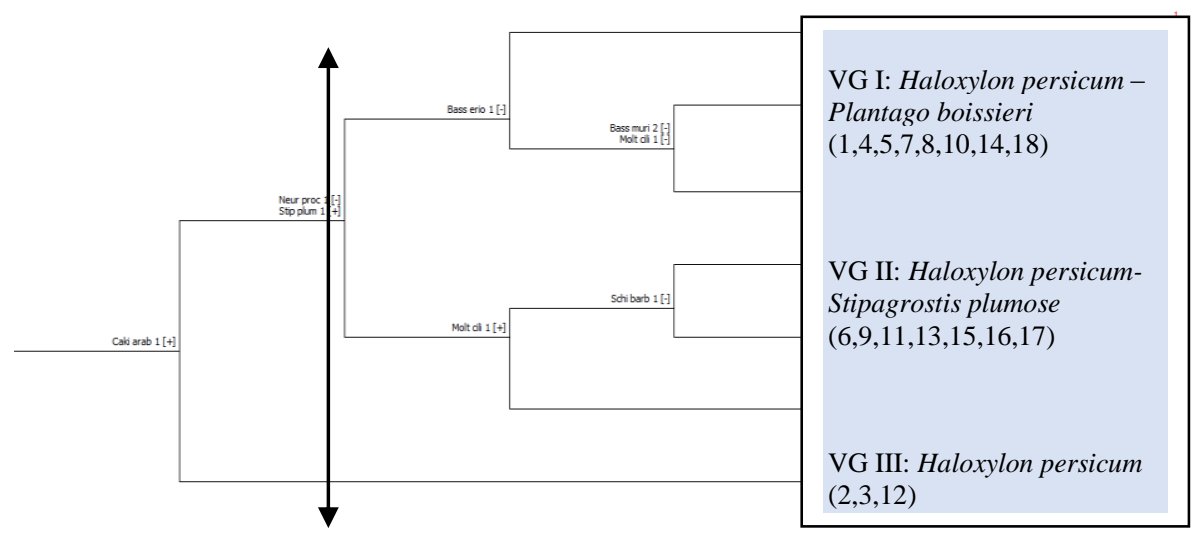

(a)

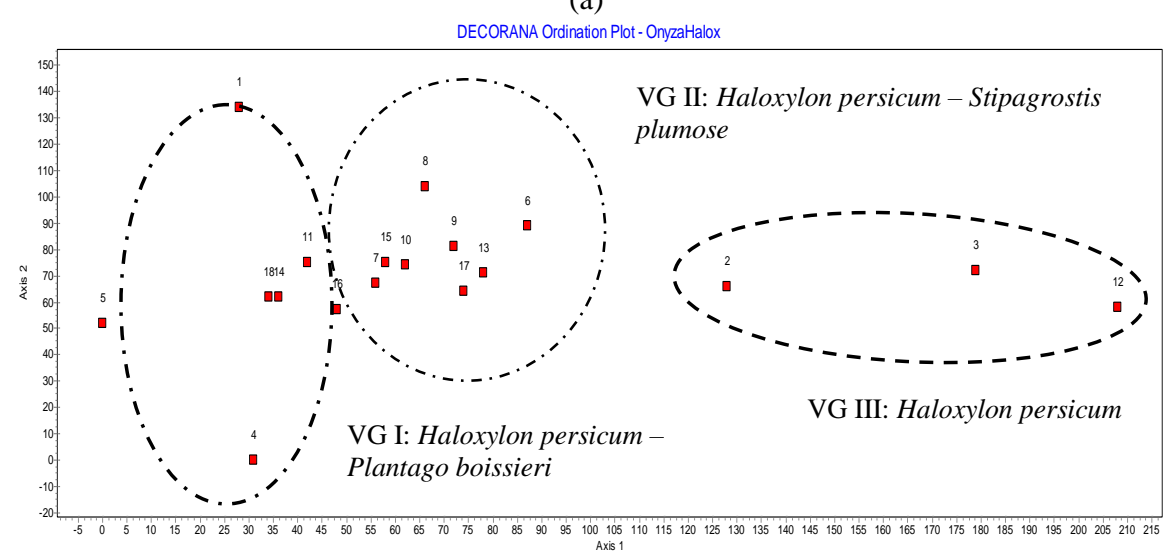

(b)

Figure 3. Results of TWINISPAN classification of the dataset ( 35 species $\times 18$ stands) (a) and DECORANA ordination of the same dataset by using the average values of three associations and sub-associations (b). In figure (a) numbers represent stands

Table 2. Inter set correlations of environmental variables with CCA axes

\begin{tabular}{|c|c|c|c|c|c|}
\hline $\mathbf{N}$ & NAME & AX1 & AX2 & AX3 & AX4 \\
\hline & \multicolumn{5}{|c|}{ Diversity indices } \\
\hline 1 & Species number & $0.5721 * *$ & $0.4329 *$ & 0.0456 & -0.2412 \\
\hline 2 & Species cover $\left(\mathrm{m} \mathrm{100m^{-1 } )}\right.$ & -0.0800 & 0.2491 & 0.6075 & -0.4776 \\
\hline 3 & Species richness (sp. stand $\left.d^{-1}\right)$ & $0.6515 * *$ & 0.3991 & -0.0210 & -0.0508 \\
\hline 4 & Evenness & $0.4389 *$ & 0.0932 & 0.7337 & 0.0680 \\
\hline 5 & Shannon $(\hat{H})$ & $0.6022 * *$ & 0.2552 & 0.4411 & -0.0745 \\
\hline 6 & Simpson (C) & $-0.4804 *$ & -0.1116 & -0.6824 & -0.0354 \\
\hline \multicolumn{6}{|c|}{ Soil } \\
\hline 7 & $\mathbf{p H}$ & -0.2246 & 0.1344 & -0.1765 & 0.0461 \\
\hline 8 & $\mathbf{E C}\left(\mathrm{mS} / \mathrm{cm}^{-1}\right)$ & -0.3477 & -0.0158 & -0.1733 & -0.0041 \\
\hline \multicolumn{6}{|c|}{ Bulk soil (\%) } \\
\hline 9 & Sand & 0.3447 & -0.1759 & 0.0713 & 0.0979 \\
\hline 10 & Clay & -0.3876 & -0.0416 & 0.2336 & -0.0722 \\
\hline 11 & Silt & -0.2357 & 0.2615 & -0.2338 & -0.0894 \\
\hline 12 & Organic Matter (\%) & -0.1692 & 0.1328 & -0.0858 & 0.1074 \\
\hline \multicolumn{6}{|c|}{ Minerals (ppm) } \\
\hline 13 & $\mathbf{N a}$ & -0.1728 & -0.0220 & -0.4835 & 0.0489 \\
\hline 14 & $\mathbf{C a}$ & -0.3585 & -0.0967 & 0.0856 & -0.0386 \\
\hline 15 & $\mathbf{K}$ & -0.0725 & 0.0394 & -0.2406 & -0.0403 \\
\hline 16 & Mn & $0.4216^{*}$ & $0.5596 * *$ & -0.3983 & -0.0691 \\
\hline 17 & $\mathbf{F e}$ & 0.3755 & $0.5414 * *$ & -0.4583 & -0.0618 \\
\hline 18 & Mg & -0.0066 & 0.1783 & -0.2558 & -0.1397 \\
\hline 19 & $\mathbf{N}$ & -0.1273 & 0.2075 & -0.3100 & 0.0100 \\
\hline 20 & $\mathbf{P}$ & -0.2872 & 0.2147 & -0.4901 & 0.0513 \\
\hline
\end{tabular}

* Significant correlation $\mathrm{P} \leq 0.05 ; * *$ Significant correlation $\mathrm{P} \leq 0.01$ 


\section{Correlation analysis}

The relation between the environmental variables and ordination axes was done by CCA application (Table 2 and Figure 4). The separation of stands along the AX-1 is affected positively by species number, richness, evenness, $\mathrm{Mn}$ and negatively by Simpson index (Table 2 and Figure 4a). The species number, Mn and Fe are positively correlated with the AX-2. The distribution of $H$. persicum are located on the lower negative side of the AX-1 and correlated with EC, Na, Clay and Ca content (Figure 4b).

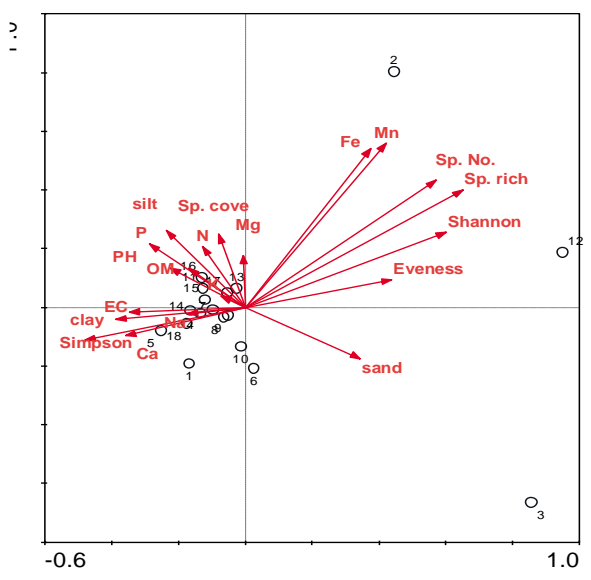

(a)

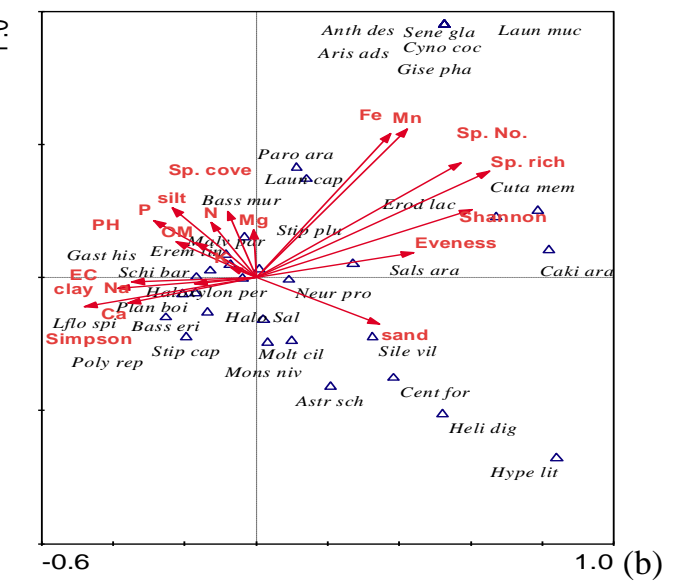

Figure 4. CANOCO ordination biplot with environmental variables (arrows); 18 stands (a) represented by circles and 35 abundant species $(b)$ represented by triangles with the first four letters of genus and three letters of species name. Fullanames of the abundant species are available in Table 1

Species number and species richness are correlated positively by $\mathrm{Fe}$ and $\mathrm{Mn}$ and negatively by clay content. Species evenness and Shannon index are correlated positively by sand and negatively by silt, $\mathrm{Na}$ and $\mathrm{P}$ but the Simpson index are correlated vice versa by these element contents (Table 3 ).

Table 3. Pearson's correlation coefficients between species diversity and soil characteristics

\begin{tabular}{|c|c|c|c|c|c|c|}
\hline Variable & Species no. & $\begin{array}{c}\text { Species cover } \\
\left(\mathrm{m}-100 \mathrm{~m}^{-1}\right)\end{array}$ & $\begin{array}{c}\text { Species } \\
\text { richness }\end{array}$ & $\begin{array}{c}\text { Species } \\
\text { evenness }\end{array}$ & $\begin{array}{c}\text { Shannon } \\
\text { index }\end{array}$ & $\begin{array}{c}\text { Simpson } \\
\text { index }\end{array}$ \\
\hline \multicolumn{7}{|l|}{ Bulk soil (\%) } \\
\hline Sand & 0.077 & -0.172 & 0.215 & $0.368^{*}$ & $0.302 *$ & $-0.327 *$ \\
\hline Silt & 0.112 & 0.139 & -0.017 & $-0.392 *$ & -0.220 & $0.314^{*}$ \\
\hline Clay & $-0.369 *$ & 0.161 & $-0.469 *$ & -0.186 & -0.324 & 0.221 \\
\hline OM & -0.231 & -0.241 & -0.127 & -0.018 & -0.147 & 0.085 \\
\hline \multicolumn{7}{|l|}{ Soil } \\
\hline pH & -0.255 & -0.095 & -0.251 & -0.310 & -0.329 & 0.282 \\
\hline $\mathrm{EC}(\mathrm{mS} / \mathrm{cm})$ & -0.260 & -0.086 & -0.299 & -0.413 & -0.420 & 0.393 \\
\hline \multicolumn{7}{|l|}{ Minerals (ppm) } \\
\hline $\mathbf{K}$ & 0.036 & -0.011 & -0.007 & -0.289 & -0.183 & 0.233 \\
\hline Mg & 0.218 & 0.079 & 0.126 & -0.283 & -0.089 & 0.199 \\
\hline $\mathrm{Ca}$ & -0.290 & -0.059 & -0.320 & -0.207 & -0.296 & 0.219 \\
\hline $\mathbf{F e}$ & $0.453 *$ & 0.016 & $0.427 *$ & -0.167 & 0.105 & 0.115 \\
\hline $\mathbf{N a}$ & -0.183 & -0.159 & -0.191 & $-0.415^{*}$ & $-0.376^{*}$ & $0.414 *$ \\
\hline Mn & $0.517 * *$ & 0.025 & $0.501 * *$ & -0.060 & 0.209 & 0.009 \\
\hline $\mathbf{N}$ & 0.108 & -0.109 & 0.094 & -0.256 & -0.128 & 0.197 \\
\hline $\mathbf{P}$ & -0.117 & -0.154 & -0.136 & $-0.433^{*}$ & $-0.362 *$ & $0.417 *$ \\
\hline
\end{tabular}

$*: \mathrm{P} \leq 0.05$ and **: $\mathrm{P} \leq 0.01$ 


\section{Soil-plant association characteristics}

The association of VG I: $H$. persicum-Plantago boissieri had the high values of species cover, silt and clay and lower values sand, Fe and Mn content (Table 4). The association of VG II: $H$. persicum- Stipagrostis plumosa had the highest values of Simpson index, organic matter, $\mathrm{pH}, \mathrm{EC}, \mathrm{K}, \mathrm{Mg}, \mathrm{Na}, \mathrm{N}, \mathrm{Fe}$ and lower in species cover, species number, species richness, species evenness and Shannon index. On the other hand, the association of VG III $H$. persicum had the highest values of species number, richness, evenness, Shannon indices, sand, Fe, Mn and lower values of Simpson index, silt, clay, organic matter, $\mathrm{pH}, \mathrm{EC}, \mathrm{K}, \mathrm{Ca}, \mathrm{Mg}, \mathrm{Na}, \mathrm{N}$ and $\mathrm{P}$ content.

Table 4. Mean \pm standard deviation of diversity indices and Soil variables of different vegetation groups in the study area

\begin{tabular}{|c|c|c|c|c|c|}
\hline VG & VG I & VG II & VG III & Total & F-Value \\
\hline \multicolumn{6}{|l|}{ Diversity indices } \\
\hline Sp. no. & $7.50 \pm 1.69$ & $6.71 \pm 1.25$ & $11.00 \pm 4.00$ & $7.78 \pm 2.44$ & $4.84^{*}$ \\
\hline $\begin{array}{l}\text { Sp. cover } \\
\text { m } 100 m^{-1}\end{array}$ & $49.63 \pm 9.4$ & $38.14 \pm 10.19$ & $39.67 \pm 27.74$ & $43.5 \pm 13.98$ & 1.471 \\
\hline Sp. rchness & $1.67 \pm 0.43$ & $1.59 \pm 0.35$ & $2.9 \pm 0.42$ & $1.85 \pm 0.62$ & $12.63^{\text {*** }}$ \\
\hline Sp. evenness & $0.62 \pm 0.09$ & $0.51 \pm 0.09$ & $0.83 \pm 0.12$ & $0.61 \pm 0.14$ & $11.81^{\text {**** }}$ \\
\hline Shannon $\hat{\mathbf{H}}$ & $0.54 \pm 0.09$ & $0.42 \pm 0.11$ & $0.83 \pm 0.05$ & $0.54 \pm 0.17$ & $20.82^{\text {*** }}$ \\
\hline Simpson $(\mathbf{C})$ & $0.43 \pm 0.1$ & $0.57 \pm 0.12$ & $0.17 \pm 0.1$ & $0.44 \pm 0.17$ & $14.79^{* * * *}$ \\
\hline \multicolumn{6}{|l|}{ Soil bulk (\%) } \\
\hline Sand & $84.75 \pm 3.2$ & $86.57 \pm 3.21$ & $88.67 \pm 2.31$ & $86.11 \pm 3.25$ & 1.871 \\
\hline Silt & $7.75 \pm 2.49$ & $6.29 \pm 2.14$ & $5.33 \pm 2.31$ & $6.78 \pm 2.39$ & 1.426 \\
\hline Clay & $7.50 \pm 1.41$ & $7.14 \pm 1.57$ & $6.00 \pm 0.00$ & $7.11 \pm 1.41$ & 1.279 \\
\hline OM & $7.88 \pm 5.13$ & $11.71 \pm 10.23$ & $7.33 \pm 4.54$ & $9.28 \pm 7.36$ & 0.604 \\
\hline \multicolumn{6}{|l|}{ Soil } \\
\hline pH & $7.85 \pm 0.1$ & $7.91 \pm 0.08$ & $7.83 \pm 0.03$ & $7.87 \pm 0.09$ & 1.383 \\
\hline EC $(\mathrm{ms} / \mathrm{cm})$ & $0.11 \pm 0.03$ & $0.12 \pm 0.06$ & $0.07 \pm 0.01$ & $0.1 \pm 0.04$ & 1.597 \\
\hline \multicolumn{6}{|l|}{ Minerals (ppm) } \\
\hline $\mathbf{K}$ & $439.77 \pm 161.88$ & $668 \pm 530.31$ & $397.41 \pm 76.14$ & $521.47 \pm 354.16$ & 0.996 \\
\hline $\mathbf{C a}$ & $323.15 \pm 135.39$ & $300.81 \pm 109.54$ & $212.41 \pm 18.44$ & $296.01 \pm 115.81$ & 1.008 \\
\hline Mg & $574.79 \pm 148.52$ & $686.73 \pm 272.83$ & $573.57 \pm 126.21$ & $618.12 \pm 201$ & 0.639 \\
\hline $\mathrm{Fe}$ & $155.99 \pm 74.62$ & $273.42 \pm 117.88$ & $309.26 \pm 176.95$ & $227.2 \pm 123.84$ & 3.070 \\
\hline $\mathbf{N a}$ & $74.57 \pm 14.13$ & $111.83 \pm 55.07$ & $61.95 \pm 7.36$ & $86.96 \pm 39.95$ & 2.831 \\
\hline Mn & $17.7 \pm 12.39$ & $28.84 \pm 14.92$ & $39.05 \pm 24.39$ & $25.59 \pm 16.65$ & 2.324 \\
\hline $\mathbf{N}$ & $4.25 \pm 1.75$ & $10.86 \pm 10.55$ & $3.67 \pm 2.08$ & $6.72 \pm 7.25$ & 2.114 \\
\hline $\mathbf{P}$ & $106.57 \pm 29.24$ & $147.48 \pm 47.74$ & $86.31 \pm 20.4$ & $119.1 \pm 42.43$ & $3.700^{*}$ \\
\hline
\end{tabular}

The plant associations identified after TWINSPAN are as the follows: VG I: Haloxylon persicumPlantago boissieri; VG II: Haloxylon persicum-Stipagrostis plumosa; VG III: Haloxylon persicum. The higher and lower value are in bold. *: $\mathrm{P} \leq 0.05, * *: \mathrm{P} \leq 0.01, * * *: \mathrm{P} \leq 0.001$

\section{H. persicum size structure}

The northern part of the studied area is characterized by high density number and lower values of plants' height, diameter, height/diameter ratio and size index as compared to the southern region of the studied area (Table 5).

The size structure of $H$. persicum individuals in the northern sector and in all over the study managed area showed an inversed-J shape approving that there is a growth of individuals toward the medium individuals which constitutes the highest percentage (Figure 5). On the other hand, the size structure frequency of $H$. persicum growing in the southern sector of the study area showed a bi-modal pattern of growth indicating 
that there is equal of juvenile and medium individuals age (Figure $5 c$ ). This could be considered as an indicator of dangers threatens the $H$. persicum individuals in the southern studied area.

Table 5. Demographic analysis of Haloxylon persicum in the study area

\begin{tabular}{c|c|c|c|c|c}
\hline Sector & Density (ha) & Height $(\mathbf{c m})$ & Diameter $(\mathbf{c m})$ & H:D $(\mathbf{c m})$ & Size index \\
\hline North (1-12) & 164.28 & $190.16 \pm 82.94$ & $210.25 \pm 126.61$ & $1.04 \pm 0.38$ & $200.21 \pm 101.5$ \\
South (13-18) & 137.84 & $250.95 \pm 184.11$ & $235.06 \pm 136.81$ & $1.08 \pm 0.70$ & $243.01 \pm 144.8$ \\
\hline Total Mean \pm SD & 301.86 & $207.48 \pm 123.88$ & $217.47 \pm 129.88$ & $1.05 \pm 0.06$ & $212.66 \pm 117.1$ \\
\hline
\end{tabular}
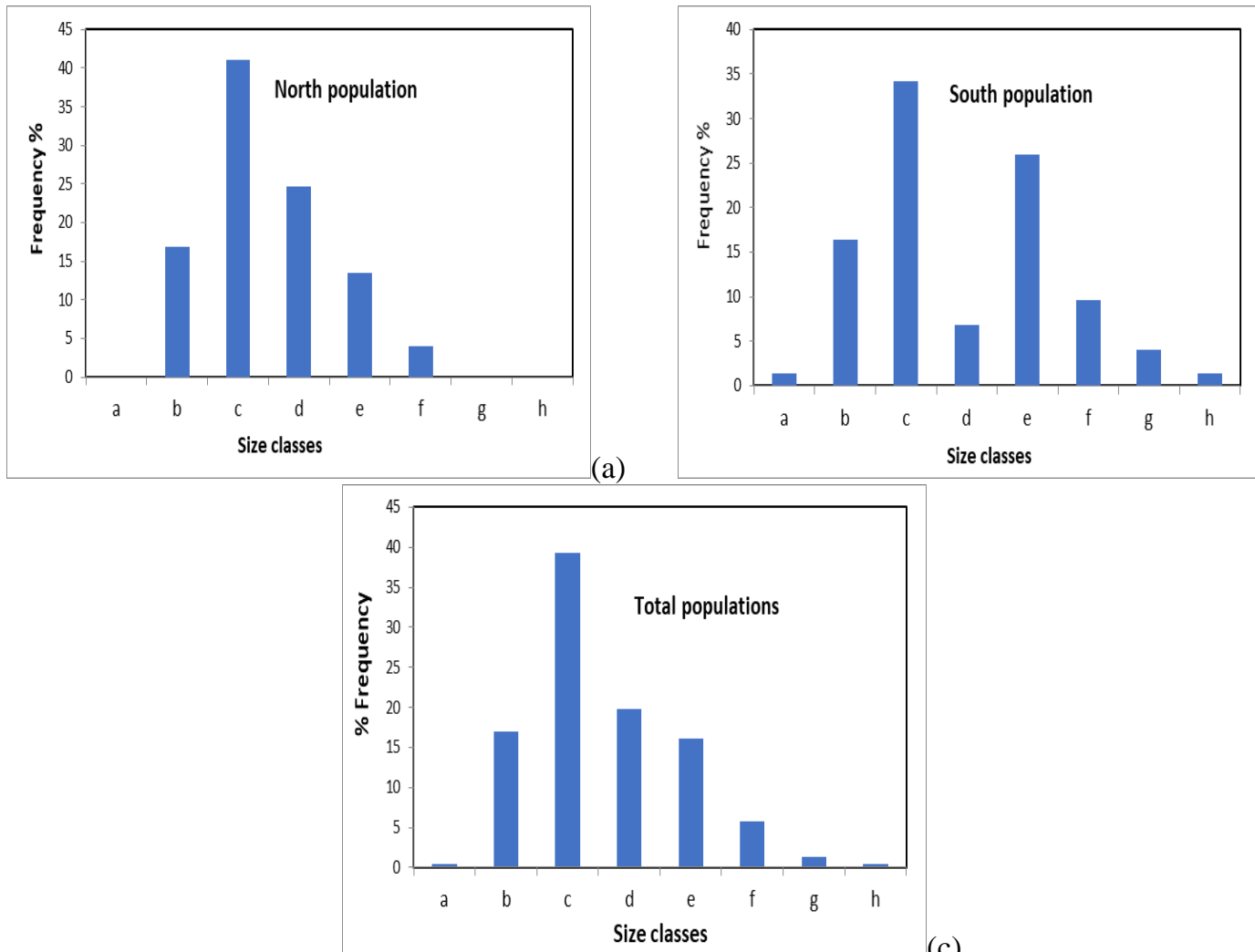

(c)

Figure 5. The size-frequency distribution of the Haloxylon persicum in the study area. The size classes cm ind.-1 are: $a<40, b: 41-100, c: 101-200, d: 201-300, e: 301-400, f: 401-500, g: 501-$ 600 and $h>600$

\section{Discussion}

Topography and land forms significantly influence the growth, existence and distribution of different plant life forms in arid and semi-arid regions (Kassas and Girgis, 1964; Zohary, 1973; Shaltout et al., 2010) such as the managed area of Unaizah; the studied area. The results obtained in this study indicated that the dominant life form in the study site is annual herbs. This dominance of annual herbs could be attributed to the abundance of water during rainy seasons which supporting the growth of such plants on these $H$. persicum Nabkhas. Moreover, these Nabkhas are considering as shelter for many therophytes because it is modified the soil substrates by retain with rainfall under soil surface (Schulz and Whitney, 1986; Shaltout and Mady, 1996; Hosni and Hegazy, 
1996; Shaltout et al., 2010). However, this water is adequate to support the growth of sub-shrubs e.g. H. persicum; therefore, the existence of such plants may be due to their adaptation to the harsh conditions exist in the study site (Alatar et al., 2012). The composition of vegetation life forms in the study area showed a typical pattern of the desert flora dominated by xerophytes and chamaephytes. The same pattern of vegetation was observed in different desert habitats among different parts of Saudi Arabia (Collenette, 1985, 1998, 1999; El-Demerdash et al., 1994; Chaudhary, 2001; Al-Turki and Al-Olayan, 2003; Fahmy and Hassan, 2005; El-Ghanim et al., 2010). In general, there is a great correlation between the plants' life forms and topography of their habitats (Kassas and Girgis, 1964; Zohary, 1973; Shaltout et al., 2010).

In study site, the dominant plant chorotype is the Saharo Arabian. The species of Saharo Arabian chorotype are distributed only along the central strip of Saudi Arabia and are more abundant in habitats providing protection and/or habitats characterized by more favorable micro-climate conditions (Zohary, 1973; Hegazy et al., 1998; El-Ghanim et al., 2010; Ghazanfar and Fisher, 2013). The central region of Saudi Arabia covers a wide range of bioclimatic zones and characterized by the existence of different habitats that supports several other chorotypes which were found in the study area beside the Saharo Arabian species e.g. the Mediterranean, Irano Turanian and Somali Masai. Furthermore, the Central region of Saudi Arabia covers the transition zone between these regions (Zohary, 1973; Mandaville, 1990; White and Léonard, 1990; Hegazy et al., 1998; Alfarhan, 1999; Ghazanfar and Osborne, 2010).

The three associations (VG) I: Haloxylon persicum-Plantago boissieri, VG II: H. persicum-Stipagrostis plumosa, VG III: H. persicum are comparable to the previous studies and represented the open sandy desert shrubland in center Saudi. This open shrubland is the most widespread community in An Nafud and corresponds to Vesey-Fitzgerald's (1957) 'central Arabian red sand vegetation' and the 'abal-'adhir sand shrubland described by Mandaville (1990). It is found near the mid-upper parts of dunes and also on undulating sheets of deep sand. Annual and perennial herbs are commonly associated with these communities of $H$. persicum Nabkhas such as Plantago boissieri, Stipagrostis plumosa, Moltkiopsis ciliata, Monsonia heliotropoides, Stipa capensis, Centropodia fragilis and Cyperus conglomeratus (Chaudhary, 1983). The distribution of plants and diversity are correlated with some edaphic factors, such as $\mathrm{Mn}, \mathrm{Fe} \mathrm{EC}$, Na, clay and $\mathrm{Ca}$ content. Many authors stated that the climate, topography and habitat heterogeneity (John et al., 2007), seed and fruits dispersal (Svenning et al., 2008) and biotic interactions (Richards et al., 1997; Araújo and Guisan, 2006). However, determinants of species distributions vary on spatial and temporal scales. For instance, climate appears to be important at the landscape level and above (Davis and Shaw, 2001; Walther et al., 2002). Soil or topography dominates at landscape and local scales, hydrology at local scales, and dispersal functions at all scales (Angert and Schemske, 2005). Moreover, our finding indicated that the species diversity is positively correlated with soil content of soil Fe, Mn and sand content; and has a negative correlation with soil silt clay and $\mathrm{Na}$ content. Other studies reported the same pattern of correlation in desert habitats of Saudi Arabia (El-Demerdash et al., 1994; Abbadi and El-Sheikh, 2002; El-Sheikh et al., 2010, 2013, 2018).

The results obtained via the analysis of size structure and frequency of $H$. persicum plants in the studied area showed an inversed-J shape approving that there is a significant growth of these plants all over the protected area as the young individuals constitute the highest percentage. Similarly, the northern part of the studies area showed 
the inversed-J pattern of size structure percentages showing that juvenile and medium individuals of $H$. persicum plants represent the highest percentages among all the other age categories. On the other hand, frequency calculation of size structure of $H$. persicum plants growing in the southern part of the studied area showed a bi-modal pattern of growth indicating that there is a significant abundance of young individuals and old individuals as well in the similar area (El-Sheikh, 2013). This could be considered as an indicator of dangers threatens the $H$. persicum community in the studied area. The obtained result showed significant evidence that $H$. persicum plants in managed area of Unaizah goes under a great negative human impact threating their abundance in the studied area (El-Sheikh, 2005, 2013). Therefore, these plants should be protected via all available means. Over-grazing and wood cutting are considered among the main factors affecting the abundance of $H$. persicum plants. The removal of $H$. and Calligonium for fuel is widespread as it is long and clean burning.

Acknowledgements. This scientific paper contains studies and research results supported by King Abdulaziz City for Science and Technology grant no. (1-17-01-001-0032).

\section{REFERENCES}

[1] Abbadi, G. A., El-Sheikh, M. A. (2002): Vegetation analysis of Failaka Island (Kuwait). - Journal of Arid Environments 50: 153-165.

[2] Al-Turki, T., Al-Olayan, H. (2003): Contribution to the flora of Saudi Arabia: Hail region. - Saudi journal of biological sciences 10: 190-222.

[3] Alatar, A., El-Sheikh, M. A., Thomas, J. (2012): Vegetation analysis of Wadi Al-Jufair, a hyper-arid region in Najd, Saudi Arabia. - Saudi Journal of Biological Sciences 19: 4354.

[4] Alatar, A. A., El-Sheikh, M. A. R., Thomas, J., Hegazy, A. K., El Adawy, H. A. (2015): Vegetation, Floristic Diversity, and Size-Classes of Acacia gerrardii in an Arid Wadi Ecosystem. - Arid Land Research and Management 29: 335-359.

[5] Alfarhan, A. (1999): A phytogeographical analysis of the floristic elements in Saudi Arabia. - Pakistan Journal of Biological Sciences (Pakistan) 2: 702-711.

[6] Allen, S. E. (1989): Chemical analysis of ecological materials. - Blackwell Scientific, Oxford.

[7] Angert, A. L., Schemske, D. W. (2005): The evolution of species' distributions: reciprocal transplants across the elevation ranges of Mimulus cardinalis and M. lewisii. - Evolution 59: 1671-84.

[8] Araújo, M. B., Guisan, A. (2006): Five (or so) challenges for species distribution modelling. - Journal of Biogeography 33: 1677-1688.

[9] Brown, G., Porembski, S. (1998): Flora and vegetational aspects of miniature dunes in a sand-depleted Haloxylon salicornicum community in the Kuwait desert. - Flora 193: 133140.

[10] Canfield, R. H. (1941): Application of the Line Interception Method in Sampling Range Vegetation. - Journal of Forestry 39: 388-394.

[11] Chaudhary, S. A. (1983): Vegetation of the Great Nefud. - Journal of the Saudi Arabian Natural History Society 2: 2-7.

[12] Chaudhary, S. A. (2001): Flora of the Kingdom of Saudi Arabia. - Ministry of Agriculture and Water, Riyadh.

[13] Collenette, S. (1985): An illustrated guide to the flowers of Saudi Arabia. - Scorpion publishing Ltd, Riyadh. 
[14] Collenette, S. (1998): A Checklist of Botanical Species in Saudi Arabia. - International Asclepiad Society, West Sussex (UK).

[15] Collenette, S. (1999): Wildflowers of Saudi Arabia. - National Commission for Wildlife Conservation and Development (NCWCD), Riyadh.

[16] Cooper, D. J., Sanderson, J. S., Stannard, D. I., Groeneveld, D. P. (2006): Effects of longterm water table drawdown on evapotranspiration and vegetation in an arid region phreatophyte community. - Journal of Hydrology 325: 21-34.

[17] Crisp, M. D., Lange, R. T. (1976): Age Structure, Distribution and Survival under Grazing of the Arid-Zone Shrub Acacia burkittii. - Oikos 27: 86-92.

[18] Cui, Y., Shao, J. (2005): The Role of Ground Water in Arid/Semiarid Ecosystems, Northwest China. - Groundwater 43: 471-477.

[19] Davis, M. B., Shaw, R. G. (2001): Range Shifts and Adaptive Responses to Quaternary Climate Change. - Science 292: 673.

[20] El-Demerdash, M., Hegazy, A., Zilay, A. (1994): Distribution of the plant communities in Tihamah coastal plains of Jazan region, Saudi Arabia. - Vegetatio 112: 141-151.

[21] El-Ghanim, W. M., Hassan, L. M., Galal, T. M., Badr, A. (2010): Floristic composition and vegetation analysis in Hail region north of central Saudi Arabia. - Saudi Journal of Biological Sciences 17: 119-128.

[22] El-Sheikh, M. A. (2005): Plant succession on abandoned fields after 25 years of shifting cultivation in Assuit, Egypt. - Journal of Arid Environments 61: 461-481.

[23] El-Sheikh, M. A., Abbadi, G. A., Bianco, P. M. (2010): Vegetation ecology of phytogenic hillocks (nabkhas) in coastal habitats of Jal Az-Zor National Park, Kuwait: Role of patches and edaphic factors. - Flora-Morphology, Distribution, Functional Ecology of Plants 205: 832-840.

[24] El-Sheikh, M. A. (2013): Population structure of woody plants in the arid cloud forests of Dhofar, southern Oman. - Acta Botanica Croatica 72: 97-111.

[25] El-Sheikh, M. A., Thomas, J., Alatar, A. A., Hegazy, A. K., Abbady, G. A., Alfarhan, A. H., Okla, M. I. (2013): Vegetation of Thumamah Nature Park: a managed arid land site in Saudi Arabia. - Rendiconti Lincei 24: 349-367.

[26] El-Sheikh, M. A., Al-Oteiby, S. A., Alfarhan, A. H., Barcelo, D., Picó, Y., Alatar, A. A., Javed, S. B., Eid, E. M. (2018): Distribution of soil organic carbon in Wadi Al-Thulaima, Saudi Arabia: A hyper-arid habitat altered by wastewater reuse. - CATENA 170: 266271.

[27] Elmore, A. J., Manning, S. J., Mustard, J. F., Craine, J. M. (2006): Decline in alkali meadow vegetation cover in California: the effects of groundwater extraction and drought. - Journal of Applied Ecology 43: 770-779.

[28] Fahmy, A., Hassan, L. (2005): Plant diversity of wadi el Ghayl, Aseer Mountains, Saudi Arabia. - Egyptian Journal of Desert Research 55: 39-52.

[29] Gaston, K. J. (2009): Geographic range limits: achieving synthesis. - Proceedings of the Royal Society B: Biological Sciences 276: 1395-1406.

[30] Ghazanfar, S. A., Osborne, J. (2010): Conservation through restoration: study of a degraded gravel plain in South Eastern Arabia. - Pakistan Journal of Botany 42: 193-204.

[31] Ghazanfar, S. A., Fisher, M. (2013): Vegetation of the Arabian peninsula. - Springer Science \& Business Media, London.

[32] Hegazy, A. K., El-Demerdash, M. A., Hosni, H. A. (1998): Vegetation, species diversity and floristic relations along an altitudinal gradient in south-west Saudi Arabia. - Journal of Arid Environments 38: 3-13.

[33] Hill, M. O. (1979a): DECORANA: A FORTRAN Program for Detrended Correspondence Analysis and Reciprocal Averaging. - Section of Ecology and Systematics, Cornell University, NY.

[34] Hill, M. O. (1979b): TWINSPAN: A FORTRAN Program for Arranging Multivariate Data in an Ordered Two-way Table by Classification of the Individuals and Attributes. Section of Ecology and Systematics, Cornell University, NY. 
[35] Holzapfel, C., Tielbörger, K., Parag, H. A., Kigel, J., Sternberg, M. (2006): Annual plantshrub interactions along an aridity gradient. - Basic and Applied Ecology 7: 268-279.

[36] Hosni, H. A., Hegazy, A. K. (1996): Contribution to the flora of Asir, Saudi Arabia. Candollea 51: 169-202.

[37] Huang, J., Yu, H., Guan, X., Wang, G., Guo, R. (2015): Accelerated dryland expansion under climate change. - Nature Climate Change 6: 166.

[38] Imada, S., Yamanaka, N., Tamai, S. (2008): Water table depth affects Populus alba fine root growth and whole plant biomass. - Functional Ecology 22: 1018-1026.

[39] John, R., Dalling, J. W., Harms, K. E., Yavitt, J. B., Stallard, R. F., Mirabello, M., Hubbell, S. P., Valencia, R., Navarrete, H., Vallejo, M., Foster, R. B. (2007): Soil nutrients influence spatial distributions of tropical tree species. - Proceedings of the National Academy of Sciences 104: 864.

[40] Kassas, M., Girgis, W. A. (1964): Habitat and Plant Communities in the Egyptian Desert: V. The Limestone Plateau. - Journal of Ecology 52: 107-119.

[41] Kent, M. (2012): Vegetation Description and Data Analysis: A Practical Approach. John Wiley \& Sons, Chichester.

[42] Magurran, A. E. (1988): Diversity indices and species abundance models. - In: Magurran, A. E. (ed.) Ecological Diversity and Its Measurement. Dordrecht: Springer Netherlands.

[43] Mandaville, J. P. (1990): Flora of Eastern Saudi Arabia. - Routledge, London.

[44] McCluney, K. E., Belnap, J., Collins, S. L., González, A. L., Hagen, E. M., Nathaniel Holland, J., Kotler, B. P., Maestre, F. T., Smith, S. D., Wolf, B. O. (2012): Shifting species interactions in terrestrial dryland ecosystems under altered water availability and climate change. - Biological Reviews 87: 563-582.

[45] Naumburg, E., Mata-gonzalez, R., Hunter, R. G., McLendon, T., Martin, D. W. (2005): Phreatophytic Vegetation and Groundwater Fluctuations: A Review of Current Research and Application of Ecosystem Response Modeling with an Emphasis on Great Basin Vegetation. - Environmental Management 35: 726-740.

[46] Orellana, F., Verma, P., Loheide II, S. P., Daly, E. (2012): Monitoring and modeling water-vegetation interactions in groundwater-dependent ecosystems. - Reviews of Geophysics 50: 1-24.

[47] Padilla, F. M., Pugnaire, F. I. (2007): Rooting depth and soil moisture control Mediterranean woody seedling survival during drought. - Functional Ecology 21: 489495.

[48] Pennisi, E. (2005): Sky-High Experiments. - Science 309: 1314.

[49] Pielou, E. C. (1975): Ecological diversity. - Wiley, NY.

[50] Reynolds, J. F., Smith, D. M., Lambin, E. F., Turner II, B. L., Mortimore, M., Batterbury, S. P. J., Downing, T. E., Dowlatabadi, H., Fernandez, R. J., Herrick, J. E., HuberSannwald, E., Jiang, H., Leemans, R., Lynam, T., Maestre, F. T., Ayarza, M., Walker, B. (2007): Global desertification: building a science for dryland development. - Science 316: 847-851.

[51] Richards, C., Haro, R., Johnson, L., Host, G. (1997): Catchment and reach-scale properties as indicators of macroinvertebrate species traits. - Freshwater Biology 37: 219230.

[52] Schulz, E., Whitney, J. (1986): Vegetation in north-central Saudi Arabia. - Journal of arid environments 10: 175-186.

[53] Shaltout, K. H., Mady, M. A. (1996): Analysis of raudhas vegetation in central Saudi Arabia. - Journal of Arid Environments 34: 441-454.

[54] Shaltout, K. H., Sheded, M. G., Salem, A. I. (2010): Vegetation spatial heterogeneity in a hyper arid Biosphere Reserve area in north Africa. - Acta Botanica Croatica 69: 31-46.

[55] Svenning, J.-C., Normand, S., Kageyama, M. (2008): Glacial refugia of temperate trees in Europe: insights from species distribution modelling. - Journal of Ecology 96: 11171127. 
[56] ter Braak, C. J. F., Smilauer, P. (2002): CANOCO Reference Manual and CanoDraw for Windows User's Guide: Software for Canonical Community Ordination (version 4.5). Ithaca NY, USA: www.canoco.com.

[57] Walther, G.-R., Post, E., Convey, P., Menzel, A., Parmesan, C., Beebee, T. J. C., Fromentin, J.-M., Hoegh-Guldberg, O., Bairlein, F. (2002): Ecological responses to recent climate change. - Nature 416: 389-395.

[58] Wang, P., Zhang, Y., Yu, J., Fu, G., Ao, F. (2011): Vegetation dynamics induced by groundwater fluctuations in the lower Heihe River Basin, northwestern China. - Journal of Plant Ecology 4: 77-90.

[59] White, F., Léonard, J. (1990): Phytogeographical links between Africa and southwest Asia. - Flora et Vegetation Mundi 9: 229-246.

[60] Zohary, M. (1973): Geobotanical foundations of the Middle East. - Gustav Fischer Verlag, Stuttgart. 